This item was submitted to Loughborough's Research Repository by the author.

Items in Figshare are protected by copyright, with all rights reserved, unless otherwise indicated.

\title{
The international consequences of Brexit: an English School analysis
}

\section{PLEASE CITE THE PUBLISHED VERSION}

https://doi.org/10.1080/07036337.2019.1665656

\section{PUBLISHER}

Informa UK Limited, trading as Taylor \& Francis Group

VERSION

AM (Accepted Manuscript)

\section{PUBLISHER STATEMENT}

This is an Accepted Manuscript of an article published by Taylor \& Francis in Journal of European Integration on 13 September 2019, available online: http://www.tandfonline.com/10.1080/07036337.2019.1665656.

\section{LICENCE}

CC BY-NC-ND 4.0

\section{REPOSITORY RECORD}

Wilson, Peter, and Tim Oliver. 2019. "The International Consequences of Brexit: An English School Analysis". figshare. https://hdl.handle.net/2134/11866209.v1. 


\title{
The International Consequences of Brexit: An English School Analysis
}

Peter Wilson (Department of International Relations, London School of Economics and Political Science, Houghton Street, London WC2A 2AE p.c.wilson@1se.ac.uk)

Tim Oliver (Institute for Diplomacy and International Governance, Loughborough University London, Queen Elizabeth Park, London E20 3BS t.l.oliver@,lboro.ac.uk)

Acknowledgements This is a revised version of papers presented at the EISA conference, Barcelona, September 2017, and the ISA conference, San Francisco, April 2018. We are grateful for the many helpful comments and suggestions received, and especially to Spyros Economides and Olivia Nantermoz who carefully read and commented on a later draft.

\begin{abstract}
The English School is one of the main traditions of thought in International Relations and the only one home-grown in Britain. While initially unconcerned with questions of integration, and the regional level more generally, its concepts and insights have recently been applied to the European integration process. However, an English School analysis of the consequences of Brexit has yet to be conducted. This article rectifies this omission and offers a broad system-level analysis of major-state withdrawal from deep multilateral arrangements. Following a brief introduction to the main phases of English School development, the article analyses the consequences of Brexit in terms of three central areas: the pluralist-solidarist debate; primary institutions; and great power status. It finds that while the adjustment costs of Brexit will be considerable, the longer-term systemic consequences are unlikely to be far-reaching. The main consequence is the additional pressure Brexit puts on Britain's precarious great power status.
\end{abstract}

Key Words Brexit; English School; International Society; Primary Institutions; Pluralism; Solidarism; Great Powers

Uncertainty has overhung Britain and Europe since the decision of the British people in June 2016 to leave the European Union (EU). 'Brexit' has been the dominant fact in British politics, and how it is handled, along with the settlement that is reached, will have far-reaching implications for British political, social, economic, and international life for many years to come. Given Britain's size and significance in the European project it will also have profound implications for the EU. 
The complexities of Brexit, in both process and outcome, have been explored by an extensive range of scholars within Political Science and European Studies (for a review see Oliver 2019). Within International Relations (IR), with a few exceptions (Simms 2016), study has been largely confined to the possible implications for the EU's aspirations in the foreign, security and defence fields (Biscop 2018), or for Britain's own foreign policy outlook (Sanders and Houghton 2016; Wright 2017). This article takes a more general, systemic perspective by applying the concepts and insights of the English School (ES) of International Relations (IR). The ES is now widely acknowledged as one of six or seven major IR theoretical traditions of world scale, and the only one home grown in Britain. While many of its leading proponents are not English, nor British, it represents in many respects a culturally and intellectually British outlook. It is also an outlook which places great weight on the normative structure of international society. It is precisely this normative structure that many fear Brexit will substantially disturb. Given this, and the recent incursion of ES thinking into the field of European integration (e.g. Diez and Whitman 2002; Stivachtis and Webber 2011), an ES analysis of Brexit is long overdue.

The ES is not a policy science, so we do not suppose it will tell us precisely what Britain or the EU27 should do at any given point of the negotiations. Nor is it a predicative theory, so we do not suppose it will forecast the outcome of these negotiations, nor project the precise state of British-EU relations much into the future. However, as a 'societal approach' (Buzan 2014) concerned with the norms, rules and institutions of international life, we do expect the ES to tell us something significant about the systemic implications of Brexit and its broad consequences for Britain.

The paper begins with an overview of the school for those unfamiliar with its major tenets. Three main areas of ES concern are identified that relate to Brexit: the tension between pluralist and solidarist conceptions of international society; the nature and role of primary institutions; and the source and significance of great power status. Each of these is then examined in relation to Brexit, focusing on the (potentially) shifting institutional landscape, the pluralist reaction to solidarism, and the risks posed to Britiain's great power status. The article concludes that while the systemic consequences of Britain's withdrawal from the EU are unlikely to be deep or farreaching, the consequences for Britain's continued great power status are likely to be profound.

\section{The English School: Overview}


The ES is a body of theory about international relations with its tap root in the Department of International Relations at LSE and significant side roots at the universities of Cambridge, Oxford, Aberystwyth and increasingly far beyond Britain. Its evolution is comprised of four overlapping phases, with the British Committee on the Theory of International Politics (19541985) being an important vehicle for the development of the first two (Vigezzi 2005). The first phase was concerned with the formal structure of the international system, particularly the sovereignty principle, the role of international law, the balance of power and the role of great powers. During this phase seminal contributors to the school such as C. A. W. Manning, Hedley Bull, Herbert Butterfield, Martin Wight, and Alan James established the main components of the system, the principal ways they related, and the character of the system thereby produced. It was during this phase that the core concept of the school, international society, was established, and its chief practical concern, the bases of international order, given wide-ranging attention (e.g. James 1973; Bull 1977). The latter concern should come as no surprise given the phase was roughly coterminous with the Cold War. The great powers were considered by far the most important actors in the system, with small states (especially in the South) and nonstate actors receiving little attention. Indeed, the school's emphasis on the primacy of the state, the role of great powers, and the balance of power, led some to conclude that the ES was not a distinctive school of thought but a variant of political realism (e.g. Brown 2001). Structure prevailed over process, continuity over change, and order over justice — with some reading an unconscious normative bias into this hierarchy of concern (e.g. Callaghan 2004).

The second phase concerned the expansion of international society, i.e. the worldwide geographical expansion of the initially European club of states. The impetus for this series of studies was concern about the implications of this expansion for international order. The importance of the cultural basis of international order had been established during the first phase of scholarship. It was therefore logical to ask, in the wake of the unravelling of the Western colonial empires in Asia and Africa in the 1960s and 1970s, and the admittance of formerly subject territories into the international club, what were the implications of the stretching of the cultural basis of society for international order (Bull and Watson 1984)? From the early concern about international order, ES attention shifted to the nature of the process. Keene (2002), for example, developed what might be called a proto-postcolonial account of the centrality of colonial expansion to European political self-identity, the European club of states from the outset resting on notions of exclusivity and superiority. Buzan (2010) identified Vanguardist and Syncretist accounts of the expansion story, mirroring the earlier debate among 
economic historians between metropolitan and peripheral theories of nineteenth century imperialism (e.g. Cain and Hopkins 2016, 33-72). Most recently Dunne and Reus-Smit (2017) have challenged the eurocentrism and linearity of the standard Bull and Watson account.

Overlapping this phase, from the 1980s the ES developed a concern about human rights and the purposes of international society. Order remained the chief concern, but richer accounts challenging the order-justice dichotomy began to appear, inspired by Vincent's seminal (1986) study of human rights. Under Vincent's influence much of the debate was framed in terms of Bull's (1966) distinction between solidarist and pluralist conceptions of international society. In Bull's original formulation solidarists emphasized 'the solidarity, or potential solidarity, of the states comprising international society, with respect to the enforcement of the law'. Pluralists by way of contrast stressed the lack of solidarity and the capability of agreement 'only for certain minimum purposes' (Bull, 1966: 52). Later formulations, however, broadened the notions-responding to developments in international political theory, not the least Nardin's (1983) distinction between practical and purpose associations, and Brown's (1993) analysis of the communitarian-cosmopolitan divide. Few now would disagree with Buzan's (2014: 16) definition of pluralism as 'the communitarian disposition towards a state-centric mode of association in which sovereignty and non-intervention serve to contain and sustain cultural and political diversity'; solidarism being 'the disposition either to transcend the statessystem with some other mode of association or to develop it beyond the logic of coexistence to one of cooperation on shared projects'. A central empirical question became the extent to which growth in concern for human rights was propelling the society of states in a solidarist direction, with some arguing for a critical international society approach in which the normative potential of international society would become progressively unlocked (Wheeler 2000; Linklater and Suganami 2006). Others meanwhile clung to a more conservative, nominally detached approach, wary of aspirations going beyond the limited capacity of the club of states for virtuous behaviour (Jackson 2000). In time more sophisticated solidarist accounts have been developed, distinguishing for example between cosmopolitan and statecentric solidarisms (Buzan 2014: 114-20). Similarly, more ethically positive conceptions of pluralism have been developed (Hurrell 2007; Williams 2015), shifting the focus away from reluctant acceptance of the limited normative horizons of international society in the face of cultural, ethical and political heterogeneity, towards acknowledgment of the vital role international rules and norms play in preserving valuable diversity. 
The final phase of ES development concerns the institutional bases of international society. With roots in the writings of classic ES scholars Wight and Bull, contemporary ES scholars are conducting theoretical and empirical work on the identity, function and significance of the primary or fundamental institutions of international society, including their role as markers of change (Holsti 2004). New taxonomies of primary institutions have been developed (Buzan 2004), their role in binding together regional international societies has been explored (Schouenborg 2012), and their co-constitutive relationship with international organizations such as the EU and UN investigated (Knudsen and Navari 2018). Valuable work on individual institutions has been done (Sharp and Wiseman 2008; Clark 2011; Falkner and Buzan 2019), and structural functionalist method has been employed to understand their evolution over time (Buzan and Schouenborg 2018). While questions remain about the ability to empirically ground primary institutions and arrive at a settled list (Wilson 2012), this is proving to be a highly productive phase of ES development.

\section{The English School and Brexit}

Superficially, the ES is an unpromising approach for analysing Brexit. It has had little to say about regional integration. Its interest in European integration has largely been confined to the issue of sovereignty, especially whether the creation of a new kind multinational entity such as the EU undermines the staple ES conception of sovereignty as 'constitutional independence' (James 1986; Jackson 1999). This is largely due to the level of analysis of most ES studies. While individual country studies are not unknown (e.g. James 1996), and attention to regional international societies is now a significant sub-field (e.g. Buzan and Gonzalez-Pelaez 2009; Knudsen and Navari 2018), the school prides itself in being in the business of general IR theory, concerned primarily with system-level questions. While the formation of the EEC in the 1950s and its evolution into the hybrid polity of polities of today. ${ }^{i}$ has profound regional significance, the ES has deemed its wider significance as minor. Firstly, it is granted that the EU is no mere inter-state organization, but a new 'post-Westphalian' polity, with a wide array of common policies, an elaborate institutional structure, an extensive pragmatically-evolving network of trans-border administrative relations, and (for most members) a common currency. But this is precisely what makes the EU sui generis. Contra Andrew Linklater $(1998,204)$ it is unlikely to 'become a model of post-Westphalian political organization which is emulated by regions elsewhere'. Secondly, even if this new polity evolves into a European super-state the systemic 
consequence is merely the reduction in the number of members of international society (Jackson 2007: 151-52). Either way, therefore, the steady expansion (and now the probable slight contraction) of the EU has limited consequences for international society. This is especially so for some members of the ES because part of the EU's uniqueness resides in its failure to develop a substantial defence capability and identity (Bull 1982). If such a capability and identity were in place the withdrawal of one of the two member-states possessing significant military power would have considerable consequences for international security. But defence is entrusted to NATO, and therefore the reduction in membership by one of the 'alliance within the alliance' (Bull 1982: 164) is not, as far as defence and security relationships are concerned, significant. Of course, since Bull wrote, the membership of both NATO and the EU has expanded, and the defence agenda has broadened to include a range of nonconventional threats. Yet the fact remains that responsibility for European security, especially traditional military security, resides largely with NATO.

Similarly, the ES is an unpromising starting point for thinking about Brexit because it has largely ignored economics. While exceptions to the rule are noteworthy (e.g. Mayall 1990), it is true that the economic dimension of international relations has been marginal to the school's efforts, with phenomena such as interdependence and globalisation not seriously analysed until recently (e.g. Buzan 2004; Buzan and Lawson 2015). The economic consequences of Brexit, however, have dominated debates both in Britain and the EU. The decoupling of Britain from an elaborate network of economic and financial rules and institutions, and the arrangements that will replace them, is the central subject of public debate and official negotiation. It is worth emphasising that Britain has not only become subject to these rules and institutions since joining in 1973 but it has had a major hand in shaping them, particularly the Single European Market. The ES's neglect of international political economy, let alone European political economy, means that it brings little to the economic table.

This paper contends, however, that three areas of ES scholarly endeavour provide a unique and valuable resource for ascertaining the international consequences of Brexit by placing it in a broader context. To recap these are: the pluralist-solidarist debate; the relationship between primary institutions; and the role and status of great powers. These connect to three of the four main phases of the English School's evolution. Each provides a rich history of analysis and debate that can be profitably applied to Brexit. 


\section{Pluralist-Solidarist Debate}

Hedley Bull's classic view was that international society was a pluralist association of nations. From time to time certain members harboured solidarist aspirations, most notably at the end of the two world wars when attempts were made to enshrine common principles and goals, and create new, universal organisations dedicated to their achievement. These attempts, however, were only superficially successful. In a culturally, ethically, economically and politically diverse world states rarely agree for long on common moral purposes. A period of calamitous disorder is often followed by a period of great power unity, but it seldom lasts. The common rules of international society are essentially rules of co-existence. Their purpose is to ensure that different and sometimes widely disparate political communities can live together relatively peaceably. The move from this pluralist model of peaceful coexistence to the solidarist model of common moral goals and purposes is one fraught with danger, and in Bull's view one best not made lest the delicate fabric of international society is torn apart (Bull 1984, 14). The United Nations (UN) and the network of rules and institutions it has spawned is therefore not to be interpreted as a substantial let alone revolutionary development. Rather it represents a change in the appearance of international politics, the substance remaining essentially unchanged.

Debate about the world historical significance of the UN continues (e.g. Mazower 2012), and the sceptical view propounded by Bull continues to be voiced, even at times of renewed optimism about its potential (e.g. Righter 1994). Not in doubt, however, are the extraordinary solidarist strides taken by the EEC/EC/EU. This too is a heterogeneous body, but since its foundation in the 1950s it has developed common policies in agriculture, fisheries, trade, regional development, environmental protection, nuclear energy, foreign affairs and security. 19 of its members share a common currency. The Single European Market is the largest single economic area in the world in terms of value of goods and services traded. It makes policy through several formal institutions, with democratic oversight through a directly elected parliament, and its laws enforced by single EU-wide court. Since 1993 its citizens have enjoyed a common European citizenship, albeit a 'thin' one contingent on prior national EU-member citizenship (Diez and Whitman 2002: 51-55).

There is no consensus among scholars on the political ontology of the EU, with intergovernmentalists, consociationalists, functionalists and federalists offering contrasting interpretations. Yet for ES scholars there is no doubt it is a solidarist international association, 
indeed the most solidarist association of nations yet achieved. More precisely it is hybrid of state-centric solidarism and cosmopolitan solidarism (Buzan 2014), with the former concept capturing the intergovernmental components of the EU and the latter the trans- and supranational components. Viewed from this perspective, Brexit can be interpreted as a reaction to the failure of elites, particularly in the more Euro-sceptical countries, to apply a brake to the increasing cosmopolitan solidarism of the European project. It has been a staple British view that a wider Europe is better than a deeper Europe. Indeed, part of the logic of a wider Europe is to make a deeper Europe impossible. To the consternation of many British observers, however, Europe has rarely stood still, instead becoming wider and deeper, with profound implications for national democracy.

Of course, Britain successfully negotiated a budgetary rebate, and a series of 'opt-outs' from the Schengen Area, the Social Chapter on workers' rights, the single currency, and the Charter of Fundamental Rights. In the run-up to Britain's referendum, David Cameron secured a renegotiation of Britain's membership, repeating the approach of Labour prime minister Harold Wilson before Britain's 1975 referendum (Glencross 2015). The 2016 renegotiation secured a series of changes, with the UK's exclusion from the EU's commitment to 'ever closer union' being the clearest example of resistance to cosmopolitan solidarism. However, Cameron failed to secure, as had Wilson before him, all the concessions he sought (Smith 2016). Crucially, he failed to secure concessions on free movement of labour, the EU resisting any limitation on the four principles - freedom of movement for labour, goods, services and capital—on which its Single Market is based (Oliver 2018).

One upshot of Britain's limited success in putting a brake on accelerating cosmopolitan solidarism is that it created the impression, among an electorate fed a daily diet of Euro-hostility by the popular press, that 'Europe' was set inexorably on a disagreeable course (Daddow 2012). It also created the problem that when it came to making the case for the EU in the referendum those heading the Remain campaign were themselves, with regard to several of the most important lines of EU policy and institutional development, Eurosceptics, or at least deeply uneasy about showing pro-European sentiments. This was most notable in the Prime Minister himself. Before assuming office, Cameron had helped found the Euro-sceptic Movement for European Reform, had pledged to pull Britain out of the Social Chapter, and in 2005 won the Conservative party leadership on a promise (later fulfilled) to take the Conservatives out of the European Peoples Party, the leading pan-European group of Conservative and Christian democrat parties. Leaving the group, seen by many Conservatives as 'federalist', limited 
Cameron's connections with other centre-right leaders and parties, most notably Germany's Angela Merkel and her CDU party. For Cameron, however, managing the solidarity of the Conservative party was far more important than advancing solidarity within the EU.

It was not just the Conservatives who struggled with a commitment to European solidarity. Differences over Europe had helped split the Labour party in the 1980s. Even Tony Blair, one of Britain's most pro-European prime ministers, was once described as an 'anti-anti-European' (Donnelley 2005) for his willingness to attack Eurosceptics but his reluctance to make a proEuropean case directly to the British people. One consequence of this was that when it came to the 2016 referendum many in the Remain camp found themselves arguing not for the increasingly cosmopolitan solidarist EU that did exist, but for a more limited state-centric solidarist EU they would prefer to exist. They found it hard to be passionate about the actuallyexisting EU, only the much-reformed EU of their desires.

Looked at from the perspective of the EU27, however, while costly and destabilising in the short run, Brexit may have long run advantages (Martill and Staiger 2018). Britain has never been fully committed to the EU project. It has always been half in and half out. ${ }^{\text {ii }}$ While it is not good to lose one of its oldest, largest, and wealthiest members, the prospects for a less compromised cosmopolitan solidarist development of the community are enhanced. Britain is not the only member, however, with reservations about this line of development, with Ireland, Poland, Denmark among others all having negotiated significant opt-outs of their own. Countries such as France have, not least under the leadership of Charles de Gaulle, also strongly resisted integration, unless palpably in French interests. While polling following Britain's referendum indicated a boost in public support for the EU in several member states, the challenge of overcoming resistance - or a 'constraining dissensus' (Hooghe and Marks 2009) - to further integration remains significant (Raines, Goodwin and Cutts 2017). Fear of losing another member may therefore help to normalize a Europe of multiple speeds and variable geometry (Bellamy, Lacey and Nicolaïdis 2017, 488), a prospect which deeply disconcerts Europe's cosmopolitan solidarist elites. In this regard the EU's moto, In Varietate Concordia or United in Diversity, becomes unusually pertinent: how much diversity can unity withstand? Are the ever-more complicated compromises between unity and diversity a sign of strength or weakness?

For many, not only in Britain, they are a sign of weakness. With the rise of nationalistic populism in many countries, and in the wake of Brexit, elites may well turn away from the 
ambitious cosmopolitan solidarism manifest, for example, in the attempt to devise and implement a European Constitution, to a more cautious state-centric solidarism as manifest, for example, in the pragmatic Council-led responses to the Euro and migration crises. These responses amount to an implicit recognition of the malfunctioning of cosmopolitan solidarism. It is interesting to note that of the five scenarios recently presented by the European Commission (2017) on how the Union could evolve by 2025 only one-'Scenario 5: Doing much more together'-could be unequivocally described as cosmopolitan solidarist.

\section{Primary Institutions}

Definitions of primary international institutions abound (Wilson 2012) but they can be thought of as 'set[s] of habits and practices shaped towards the realization of common goals' (Bull $1977,74)$ or 'durable and recognized patterns of shared practices rooted in values held commonly by the members of interstate societies, and embodying a mix of norms, rules and principles' (Buzan 2004: 181). The EEC/EC/EU can be seen as an evolving organization that, while not yet successfully replicated elsewhere in the world (for the ASEAN experience see Wong 2012), has nevertheless had a considerable impact on the primary institutions of international society - and not only within Europe but beyond, through its diplomatic influence, its policy of pre-accession conditionality, and by force of example. In terms of Buzan's (2004) scheme it might be contended that through the development of supranationality in certain areas (e.g. trade, management of the Euro, the environment) the master institutions of sovereignty, territoriality and nationalism have been negatively impacted, and those of the market and equality of people positively impacted. Similarly, regarding Buzan's derivative institutions, multilateral diplomacy has been strengthened and bilateral diplomacy weakened; trade and financial liberalization have been strengthened, and boundaries (i.e. the social, economic and political significance of boundaries) weakened. In terms of Holsti's (2004) scheme, the foundational institutions of sovereignty and territoriality have been weakened and law strengthened. Regarding his procedural institutions war and colonialism have been weakened and trade and the market strengthened.

To present the picture in this way is of course to present it in highly general terms. Holsti provides us with the means of arriving at a more detailed picture through his six-fold categorization of institutional change. According to Holsti (2004) institutional change can be seen in terms of: novelty/replacement; addition/subtraction; increased/decreased complexity; 
transformation; reversion; and obsolescence. In modern international society, for example, trade is a novel institution, and colonialism has become obsolete. The traditional institutions of sovereignty, international law, and diplomacy remain highly institutionalized but with much added complexity. War exhibits the most complex development, suffering deinstitutionalisation and reversion to pre-Westphalian Hobbesianism in many parts of the world, increased regulation in others, and among OECD countries, obsolescence.

In these terms the EU has added complexity to the institution of sovereignty. This has been achieved, for example, by enshrining EU law as superior to domestic law, making EU directives binding, establishing qualified majority voting in several policy areas, and by establishing demanding criteria for membership. At the same time the symbols, rituals and myths of national sovereignty have been jealously guarded, and the interpenetration of the business of national governments contrasts sharply with the continued isolation of national parliaments (Wallace 1999: 96-99). Diplomacy has also been rendered more complex through the many channels and forms it now takes within the EU. The same could be said for the market and the equality of peoples, due to the many rules now regulating economic activity within the Single Market, and the growing body of rules protecting the rights and well-being of workers, minorities, children and refugees. The sheer complexity of a member state's connections to the EU was shown by the British government itself, when between 2011-13 it undertook a comprehensive review of the EU's powers. The resulting 'Review of the Balance of Competences' produced 32 reports covering everything from taxation and transport to economic policy and the environment. To the frustration of Eurosceptics, none of the reports concluded that powers needed to be repatriated (Emerson, 2015).

While sovereignty has been rendered more complex, nationalism has been transformed. The idea of separate and distinct national interests that it is the duty of the statesperson to always put first, has been in retreat with the growth of the EU. This is not to say that member states do not sometimes put their own interests above the community. Nationalism in this sense is far from obsolete. It is to say that for the first time in the history of the modern state system a group of established nation-states - and ones that were at the centre of two world wars - have agreed to consider the interest of the wider community before acting in any given area, and to avoid actions that could be deemed 'non-communautaire'. Similarly, the balance of power-for Bull (1977, 106-7) the master institution of international society - has been radically transformed by the pooling of sovereignty (Diez, Manners and Whitman 2011, 126-7). Through the delegation of executive and legislative powers to supranational bodies such as the European 
Commission and the European Central Bank, and the forging of common policies most notably in the areas of trade and competition, member-states no longer fear the local preponderance of large powerful states. While not entirely obsolete, balancing the power of Germany or France is no longer the central game in European international politics. Finally, thanks to a combination of primarily the EU and NATO (which institutionalised the US security guarantee to Europe), war has been transformed in the relations between EU member states, from a practice frequently employed to settle differences, acquire territory, and increase power, to a measure employed exclusively against external actors and threats, and only in the most exceptional circumstances in defence of fundamental community values. In Holsti's terms it has become obsolete within the walls of the Union but highly institutionalized without.

The fact of one member, albeit a prominent one, leaving the group does not necessarily imply any reduction in the number of primary institutions at work in Europe, nor any loss of complexity, or any brake on transformation. Yet there is no question that Brexit represents the most explicit reassertion of sovereignty within the EU to date, and the most significant challenge to the retreat of nationalism. It may also breathe new life into the institution of the balance of power, as for the first time in nearly half-a-century a major western European state will be situated outside of the zone of pooled sovereignty (Krastev and Leonard 2010; Simón 2015). It would be naïve to rule out the possibility of new power dynamics, including those generated by rising German hegemony, real or perceived, especially within the Eurozone. Regarding equality of peoples, diplomacy, the market and war there is no reason to expect any significant institutional change. Brexit does entail, however, some reversion to sovereignty and nationalism as legitimating principles of what has been termed (Diez, Manners and Whitman 2011) the European regional international society (ERIS). To this extent it is a challenge to inter- and supra-nationalism.

The wider systemic consequences will be contingent on the nature of the post-Brexit relationship, in particular the extent to which Britain continues to identify with core EU values and comply with its rules and regulations (Diez and Whitman 2002: 57; Springford and Lowe 2018). It will also be contingent on the extent to which separation from the EU will attract other states, which in turn will depend on the success Britain makes of it (Martill and Staiger 2018). Perhaps the EU was too confident that the days of sovereignty were numbered; too complacent in the face of a recrudescence of nationalist sentiment? Maybe there is something in the argument that European integration has been driven by and designed for political and 
administrative elites who have grown insensitive to the attitudes and desires of their publics (Calhoun 2016; Burgoon, Oliver and Trubowitz 2017)?

\section{Great Power Status}

One issue conspicuous by its absence in the EU referendum debate was Britain's continued great power status. Many people in Britain, including among what is presumptiously called the political class, still possess a great power mindset. This is partly due to an uncritical view of Britain's 'glorious' past, its tremendous nineteenth-century industrial, technological and commercial might, the position of the Bank of England for a century as the world's central bank, its empire on which the sun never set, its indomitable navy, and its self-image of 'standing alone' against Nazism. But it is also due to its name. 'Great' Britain carries with it the assumption of great power status without having to think hard about criteria. Parliament's vote in July 2016 to replace the submarines carrying Britain's 'independent' nuclear deterrent, at a cost likely to exceed the official estimate of $£ 31 \mathrm{bn}$, can be seen in this context. Does the Trident nuclear programme give Britain much extra security? Arguably not. The threats to British security are many and varied but direct nuclear attack from an enemy nuclear power or 'nuclear blackmail' is not uppermost. France, however, has nuclear weapons, as do all permanent members of the UN Security Council (UNSC). Abandoning them, unilaterally, would reduce Britain's status in the world, bad enough vis-à-vis rising powers such as India and China, intolerable with regard to established and more local rivals such as France. This is a widely held perception, extending across the political spectrum, as the overwhelming vote in Parliament to replace the fleet testifies. The tautological nature of the argument escapes all but a few: Great Britain has to have nuclear weapons because she is great, she is great because she has nuclear weapons.

While not exercising the minds of the many, the objective basis of Britain's great power status at a time of multidimensional relative decline has certainly exercised the minds of the official few, as evidenced by the many strategic defence and other reviews seeking to specify this basis in recent decades. Within official circles 'the idea that Britain is a great power is prevalent and an influential factor in determining British foreign and defence policy' (Morris 2011, 326). Precisely what power resources it has at its disposal has been a perennial source of concern. The objective attributes of power are a central concern of political realism. It would be wrong to assume, however, that for all realists these attributes are exclusively material. For some (e.g. 
Mearsheimer 2001) this is true, at least in theory. But for others (e.g. Morgenthau 1978) in both theory and practice power is more complex. Along with population size, industrial output, strength of armed forces, technological capabilities, must be added non-material factors such as the energy and ingenuity of the population, authority and skill of leadership, public morale, even the quality of country's civilization (Gellman, 1988). To this equation the ES adds social conferment. Great power status is precisely that, a status. It is something socially conferred. This does not mean objective and material qualities are irrelevant. But great power status goes beyond the possession of certain objective material attributes, leaving the door open in ES thinking for a power to have more or less of them and still retain the status. This is a possibility of no small importance for a country such as Britain, declining in some ways (e.g. defence spending (Dempsey 2018)) but rising or at least flat-lining in others (e.g. 'soft power' (McClory 2015)). It is one to which its leaders, if not its general population, have been highly sensitive.

Britain's nuclear capability is one of several elements - including the 'special relationship' with the US, a global diplomatic and intelligence network, and a capital city that is a global financial and cultural hub - that make up her claim to great power status. Closely related is the strength and effectiveness of her conventional armed forces. But this strength has been significantly reduced in recent decades due to successive budget cuts. Absent Trident, for example, the Royal Navy is a shadow of its former self, possessing currently no operational carrier fleet. Under the latest Strategic and Defence Review the size of the army is set to shrink to its lowest level since 1815. Add to this equation the extensive strategic and operational failures in Afghanistan and Iraq, and the criticism of so many aspects of military planning and implementation in the Chilcot Report (2016), and the outlook starts to look bleak from a Great Power point of view. Some have interpreted a major recommendation of Chilcot, that in future 'all aspects of any intervention need to be calculated, debated and challenged with the utmost rigour', as meaning 'never again'. Military operations on the scale of Afghanistan or Iraq now look deeply improbable. While Britain is one of the few NATO members to meet target defence expenditure of $2 \%$ GDP, and it has deployed troops to bases in NATO allies such as Estonia, its capacity for unilateral military action overseas is limited. Britain is by no means a conventional great power.

The underlying health of the economy is the major factor in the calculus of Britain's might, as it has been for over a century (Kennedy 1981). The size and strength of the British economy therefore is a key fact in any claim to continued great power status, as the need to repeatedly assert that Britain remains the world's sixth largest economy unsubtly suggests (Morris 2011, 
331). Brexit here casts a dark and possibly long shadow over Britain. Before the referendum Britain with its relatively flexible labour market, low corporate taxation, and hospitable environment for inward investment, was among the higher performing EU economies - despite being one of the economies hardest hit by the 2008 financial crisis and ensuing recession. Since the referendum, however, it has been one of the poorest performing economies (Springford, 2018). In part this is because British government has become so consumed by Brexit that management of the economy has been neglected. It is impossible to predict how long the economic uncertainty triggered by Brexit will last, and what impact this will have on the economic fundamentals of investment, productivity and growth. Much depends on the terms of the separation and the arrangements put in place for Britain's trading and wider economic relationships (House of Commons Treasury Committee 2016; House of Commons Exiting the EU Committee 2018). Far from fearing Britain's future place in the world economy many prominent Brexiteers anticipate a bright economic future, free of the constraints and costs of a heavily bureaucratic Europe. This may come to pass, but few deny that the road will be long and difficult. Furthermore, as discussed in the previous section, the likely degree of separation and regulatory independence is much disputed. That Brexiteers and the British government have struggled to define the new relationship Britain should seek with the EU, point to the weak strategic thinking behind Brexit and Britain's confused outlook (Oliver 2017). The opportunity costs of Brexit and considerable economic and political uncertainty engendered only adds to the pressure on Britain's great power status from other sources.

Britain's decline from primus inter pares among the great powers to her current ambiguous position has been steady and relentless. The rather neglected ES scholar F. S. Northedge entitled his study of British foreign policy in the inter-war years The Troubled Giant (1966), and his successor volume taking the story up to Britain's entry into the EEC in 1973 Descent from Power (1974). For many, including the Prime Minister who took Britain into the EEC, Edward Heath, and leading figures in other political parties such as Roy Jenkins and David Owen (although Owen now backs Britain leaving the EU (Owen and Ludlow 2017)), joining the Community was a means of reducing the trouble and arresting the descent. The period 1982-2008 may come to be viewed as one in which, whether because of the EEC/EC/EU or despite it, these goals were generally achieved. But in terms of Britain's current and projected conventional armed strength, and the current and projected strength of her economy, it is hard to see the international community continuing to confer great power status on Britain long into the future. 
As part of the ongoing Brexit negotiations, Britain has been able to point to her military contributions to the defence and security of Europe, the retention of which is an important goal of some EU member states (Oliver 2018). Various proposals have been mooted as ways to allow Britain and EU to continue cooperating. Some states such as Denmark (which has an opt-out from EU defence cooperation), have continued to pursue bilateral defence links with Britain. Other proposals envisage Britain gaining some access to EU decision making in this area (Whitman 2016; Giegerich and Mölling 2018). However, institutional and legal problems combined with a desire by the EU27 to push forward with EU foreign, defence and security cooperation means Britain risks finding itself excluded or having to seek links through channels such as NATO (Martill and Sus 2018). The ambiguity of Britain's international position seems set to intensify.

Yet along with her soon-to-be-renewed nuclear forces Britain still takes its seat among the P5 on the UNSC. Does Brexit strengthen or weaken Britain's claim to this seat? There can be no doubt that Britain has been able to resist the periodic calls for revision of her position due to it being a leading member of a closely-knit association of nations which collectively represents a population of over $500 \mathrm{~m}$, with a GDP greater than the US. Put Britain outside this association, however, and her claim begins to look weaker. A lot will depend on the skill of Britain's postBrexit diplomacy, not least building new friendships and alliances and strengthening some old ones, notably with the US and within the UN (Dee and Smith 2017). It is important to note, however, that alongside her military resources Britain's diplomatic resources have been depleted in recent decades, especially across Europe. This has been partly for economic reasons, but also because of the concentration of more and more diplomatic activity in Brussels. In light of this, the Foreign and Commonwealth Office announced in 2017 that it planned to boost spending in EU capitals, largely at the cost of spending in other areas of the world (Elliott 2017). This was in recognition of the need to compensate for Britain's move from being a decision-maker in Brussels to a decision-taker and, at best, a decision-shaper. Forging a new path in the wider world, including the UN, will require similar investments in Britain's wider diplomatic network, but at a time when the public finances are under sustained pressure.

The issue of Britain's permanent seat on the UNSC, as with her great power status generally, did not arise in the EU referendum campaign. This can only be explained by complacency and ignorance - complacency over the continuation of Britain's status allied with ignorance of the effort that she daily spends in the UN system defending and protecting it. It is for example a major reason why Britain has stepped up her effort to meet the UN-defined foreign aid target 
of $0.7 \%$ gross national income. Britain is now the second largest international aid donor after the US, much of this aid being channelled through the UN. In addition, Britain is the sixth largest contributor to the UN's general budget (contributing 4.7\%) and to its peacekeeping budget (contributing 5.8\%) (Dee and Smith 2017, 528). She may not have the guns to sustain her claim to a permanent UNSC seat but she has the generosity. Despite being one of the world's smallest recognised nuclear powers, possessing just $1 \%$ of the world's stockpile of warheads, Britain is a leading player in UN nuclear diplomacy. She may not be a great power in the old sense, but she is a great responsible (Bull 1977, 288; Brown 2004). Such is the narrative Britain has been skilfully spinning. Outside of the EU it can still be spun, but the threads will need to be much stronger to bear the weight of Britain's case in the future (Kitchen and Oliver, 2017).

\section{Conclusion}

Applying ES theory to the problem of Brexit does not provide us with a clear set of probable outcomes. It highlights, however, the ongoing tension between state-centric and cosmopolitan solidarism in Europe, particularly in sensitive areas such as migration and economic and monetary union. It also suggests a reversion to the Westphalian institutions of sovereignty and nationalism, or at least a questioning of the elite aversion to these institutions which, in the absence of the development of a 'thick' European culture and identity, is unlikely to go away. Likewise, it suggests a weakening of the 'EU core' (Diez and Whitman 2002, 60) of the ERIS, or at least a rebalancing of the relationship between this core and the states that form its periphery. While adjustment problems and costs are likely to be considerable, however, the sense of community reflected and fostered in such bodies as the Council of Europe (with its European Convention on Human Rights (ECHR)), the OSCE and NATO (see Stivachtis and Webber 2011, 102), bodies which Britain has no intention of leaving (despite occasional rumblings over the ECHR), suggest that from an international society perspective the likely consequences for international order of Brexit are limited. The complex mix of insiders and outsiders that constitutes the ERIS will be made more complex, especially if Britain secures a 'bespoke' deal with the EU, but this does not imply any weakening in the common values and interests which underpin international order. It will, however, imply some adjustment in its rules and institutions. 
Even so, the dense network of rules and institutions that define the ERIS and go to the heart of the stability it has provided over the last five decades is unlikely to be significantly disturbed or diminished. For this to happen, something far more severe and significant would need to occur to the ERIS (Webber 2014; Kearns 2018). The international systemic consequences of Brexit, therefore, may not prove to be deep or far-reaching. Yet the additional pressure Brexit puts on Britain's precarious great power status cannot be ignored. This is perhaps the most important consequence of Brexit from an ES point of view. It is one that has implications not only for Britain's but also Europe's power and influence in the world. One cannot therefore rule out indirect systemic consequences of this dramatic and unprecedented realignment of Britain's international relationships.

\section{Notes}

' There is no easy way to capture the entity that is the EU. Attempts include 'multiperspectival society' (Diez, Manners and Whitman 2011) and 'multilevel political system' (Lacey 2016). Most agree that in terms of integration it is more than an international organization but less than a single polity, containing thin democratic but thicker demoi-cratic elements (Bellamy, Lacey and Nicolaïdes 2017, 490). Demoi-cracy is the normative commitment to govern together but not as one (Nicolaïdis 2013; Lord 2017).

ii Note Bull's $(1982,161)$ observation that 'There is a known antagonism of a majority of ordinary British people towards membership of the European Community, carefully kept at bay by the elite who feel (rightly, as I think) that they know better'.

\section{References}

Bellamy, R., Lacey, J., and Nicolaïdis, K. 2017. European boundaries in question? Journal of European Integration. 39, no. 5: 483-498.

Biscop, S. 2018. Brexit, strategy and the EU: Britain takes leave. Egmont Paper 100. Brussels: Egmont Institute.

Bull, H. 1966. The Grotian conception of international society. In Diplomatic investigations: essays in the theory of international politics, eds. H. Butterfield and M. Wight, 51-73. London: George Allen and Unwin.

Bull, H. 1977. The anarchical society: a study of order in world politics. London: Macmillan.

Bull, H. 1982. Civilian power Europe: a contradiction in terms? Journal of Common Market Studies 21, no. 2: 149-170.

Bull, H. 1984. Justice and International Relations. The Hagey Lectures. Waterloo: University of Waterloo.

Bull, H., and Watson, A., eds. 1984. The expansion of international society. Oxford: Oxford University Press.

Buzan, B. 2004. From international to world society? English school theory and the social structure of globalisation. Cambridge: Cambridge University Press.

Buzan, B. 2010. Culture and international society. International Affairs 86, no. 1: 1-25.

Buzan, B. 2014. An introduction to the English school of international relations: the societal approach. Cambridge: Polity.

Buzan, B., and Gonzalez-Pelaez, A., eds. 2009. International society and the Middle East: English school theory at the regional level. London: Palgrave.

Buzan, B., and Lawson, G. 2015. The global transformation: history, modernity and the making of international relations. Cambridge: Cambridge University Press.

Buzan, B., and Schouenborg, L. 2018. Global international society: a new framework for analysis. Cambridge: Cambridge University Press.

Brown, C. 1993. International political theory: new normative approaches. New York and Oxford: Columbia University Press.

Brown, C. 2001. World society and the English school: an 'international society' perspective on world society. European Journal of International Relations 7, no. 4: 423-441. 
Brown, C. 2004. Do great powers have great responsibilities? Great powers and moral agency. Global Society 18, 1: 5-19.

Burgoon, B., Oliver, T., and Trubowitz, P. 2017. Globalization, domestic politics and transatlantic relations. International Politics 54, no. 4: 420-433.

Cain, P. J., and Hopkins, A. G. 2016. British imperialism, 1688-2015. $3^{\text {rd }}$ edn. London: Routledge.

Calhoun, C. 2016. Brexit is a mutiny against the cosmopolitan elite. New Perspectives Quarterly 33, no. 3: 50 58.

Callaghan, W. 2004. Nationalising international theory: race, class and the English school. Global Society 18, no.4: $305-323$.

Chilcot, J. 2016. Report of the Iraq Inquiry. London: Cabinet Office.

Clark, I. 2011. Hegemony in international society. Cambridge: Cambridge University Press.

Daddow, O. 2012. The UK media and 'Europe': from permissive consensus to destructive dissent. International Affairs 88, no. 6: 1219-1236.

Dee, M., and Smith, K. E. 2017. UK diplomacy at the UN after Brexit: challenges and opportunities. British Journal of Politics and International Relations 19. No. 3: 527-542.

Dempsey, N. 2018. UK defence expenditure. London: House of Commons Library. http://researchbriefings.parliament.uk/ResearchBriefing/Summary/CBP-8175\#fullreport

Diez, T., and Whitman, R. 2002. Analysing European integration: reflecting on the English school - scenarios for an encounter. Journal of Common Market Studies 40, no. 1: 43-67.

Diez, T., Manners, I., and Whitman, R. 2011. The changing nature of international institutions in Europe: the challenge of the European Union. Journal of European Integration 33, no. 2: 117-138.

Donnelley, B. 2005. The Euro and British politics. European policy brief, September.

Dunne, T., and Reus-Smit, C., eds. 2017. The globalization of international society. Oxford: Oxford University Press.

Elliott, F. 2017. Asian embassies cut by Boris Johnson to fund EU diplomats. The Times, 30 December. https://www.thetimes.co.uk/article/asian-embassies-cut-by-boris-johnson-to-fund-eu-diplomatsg172m0gh7

Emerson, M. 2015. Britain's future in Europe: reform, renegotiation, repatriation or secession? Brussels: CEPS. https://www.ceps.eu/publications/britain $\% \mathrm{E} 2 \% 80 \% 99 \mathrm{~s}$-future-europe-reform-renegotiationrepatriation-or-secession

European Commission. 2017. White paper on the future of Europe: reflections and scenarios for EU27 by 2025. Brussels: European Commission. https://ec.europa.eu/commission/sites/betapolitical/files/white paper_on the future of europe en.pdf

Falkner, R., and Buzan, B. 2019. The emergence of environmental stewardship as a primary institution of global international society. European Journal of International Relations 25, no. 1: 131-55.

Gellman, P. 1988. Hans Morgenthau and the legacy of political realism. Review of International Studies 14, no. 4: 247-66.

Giegerich, B., and Mölling, C. 2018. The United Kingdom's contribution to European security and defence. Joint report by IISS and DGAP. https://www.iiss.org/en/events/events/archive/2018-41aa/februarye9fc/uk-european-defence-2410

Glencross, A. 2015. Looking back to look forward: 40 years of referendum debate in Britain. Political Insight 6, no. 1:25-27.

Holsti, K. J. 2004. Taming the sovereigns: institutional change in international politics. Cambridge: Cambridge University Press.

Hooghe, L., and Marks, G. 2009. A postfunctionalist theory of European integration: from permissive consensus to constraining dissensus. British Journal of Political Science 39, no. 1: 1-23.

House of Commons Exiting the EU Committee. 2018. Government Brexit analysis material published. London: House of Commons. 1 March. https:/www.parliament.uk/business/committees/committees-az/commons-select/exiting-the-european-union-committee/news-parliament-2017/cross-whitehallbriefing-published-17-19/

House of Commons Treasury Committee. 2016. The economic and financial costs and benefits of the UK's EU membership. London: House of Commons.

https://publications.parliament.uk/pa/cm201617/cmselect/cmtreasy/122/122.pdf

Hurrell, A. 2007. On global order: power, values and the constitution of international society. Oxford: Oxford University Press.

Jackson, R. 2000. The global covenant: human conduct in a world of states. Oxford: Oxford University Press. Jackson, R. 2007. Sovereignty: evolution of an idea. Cambridge: Polity.

Jackson, R., ed. 1999. Sovereignty at the millennium. Oxford: Blackwell.

James, A. 1986. Sovereign statehood: the basis of international society. London: George Allen and Unwin.

James, A. 1996. Britain and the Congo crisis, 1960-63. London: Macmillan. 
James, A., ed. 1973. The bases of international order. London: Oxford University Press.

Kearns, I. 2018. Collapse: Europe after the European Union. London: Biteback.

Keene, E. 2002. Beyond the anarchical society: Grotius, colonialism and order in world politics. Cambridge: Cambridge University Press.

Kennedy, P. 1981. The realities behind diplomacy: background influences on British external policy, 1865 1980. London: Fontana.

Kitchen, N., and Oliver, T. 2017. Written evidence submitted to the House of Commons Defence select committee's inquiry into 'The indispensable ally? US, NATO and UK defence relations'. House of Commons Defence Committee, 30 March 2017. http://data.parliament.uk/writtenevidence/committeeevidence.svc/evidencedocument/defencecommittee/the-indispensable-ally-us-nato-and-uk-defence-relations/written/48569.pdf

Knudsen, T., and Navari, C. eds. 2018. International organizations in the anarchical society: the institutional structure of world order. London: Palgrave.

Krastev, I. and Leonard, M. 2010. The spectre of a multipolar Europe. London: European Council on Foreign Relations.

Lacey, J. 2016. Conceptual mapping the European Union: a demoi-cratic analysis. Journal of European Integration 38, no. 1: 61-77.

Linklater, A. 1998. The transformation of political community: ethical foundations of the post-Westphalian era. Cambridge: Polity.

Linklater, A. and Suganami, H. 2006. The English school of international relations: a contemporary reassessment. Cambridge: Cambridge University Press.

Lord, C. 2017. The legitimacy of exits from the European Union. Journal of European Integration 39, no. 5: 499-513.

Martill, B.., and Staiger, U. 2018. Brexit and beyond: rethinking the futures of Europe. London: UCL Press.

Martill, B., and Sus, M. 2018. Known unknowns: EU foreign, security and defence policy after Brexit. London: Dahrendorf Forum.

Mayall, J. 1990. Nationalism and international society. Cambridge: Cambridge University Press.

Morgenthau, H. J. 1978. Politics among nations: the struggle for power and peace. 5th edn. New York: Alfred Knopf.

Morris, J. 2011. How Great is Britain? Power, responsibility and Britain's future global role. British Journal of Politics and International Relations 13, no. 3: 326-347.

Mazower, M. 2012. Governing the world: the history of an idea. London: Penguin.

McClory, J. 2015. The soft power 30: a global ranking of soft power. London: Portland. https://portlandcommunications.com/pdf/The-Soft-Power 30.pdf

Mearsheimer, J. 2001. The tragedy of great power politics. New York: Norton.

Nardin, T. 1983. Law, morality, and the relations between states. Princeton: Princeton University Press.

Northedge, F. S. 1966. The troubled giant: Britain among the great powers, 1916-39. London: Bell.

Northedge, F. S. 1974. Descent from power: British foreign policy, 1945-73. London: George Allen and Unwin.

Oliver, T. 2017. Britain's Brexit strategy: lions misled by donkeys. Dahrendorf Forum, September 2017 http://www.dahrendorf-forum.eu/britains-brexit-strategy-lions-misled-by-donkeys/

Oliver, T. (ed.) 2018. Europe's Brexit: EU perspectives on Britain's vote to leave. Newcastle upon Tyne: Agenda.

Oliver, T. 2019. 'Brexitology: delving into the books on Brexit.' International Politics Review, published online, 2 January.

Outhwaite, W. 2017. Brexit: sociological responses. London: Anthem.

Owen, D., and Ludlow, D. 2017. British foreign policy after Brexit. London: Biteback.

Raines, T., Goodwin, M., and Cutts, D. 2017. The future of Europe: comparing public and elite attitudes. London: Chatham House.

https://www.chathamhouse.org/sites/files/chathamhouse/publications/research/2017-06-20-futureeurope-attitudes-raines-goodwin-cutts-final.pdf

Righter, R. 1994. Utopia lost: the United Nations and world order. New York: Brookings.

Sanders, D. and Houghton, D.P. 2016. Losing an empire, finding a role. Basingstoke: Palgrave.

Schouenborg, L. 2012. The Scandinavian international society: primary institutions and binding forces, 1815 2010. London: Routledge.

Sharp. P., and Wiseman, G. 2008. The diplomatic corps as an institution of international society. New York: Palgrave.

Simms, B. 2016. Britain's Europe: a thousand years of conflict and cooperation. London: Allen Lane.

Simón, L. 2015. Britain, the European Union and the future of Europe: a geostrategic perspective. The RUSI Journal 160, no. 5: 16-23. 
Smith, J. 2016. David Cameron's EU renegotiation and referendum pledge: a case of déjà vu? British Politics 11, no. 3: 324-346.

Springford, J. 2018. 'What's the cost of Brexit so far?' London: Centre for European Reform.

Springford, J., and Lowe, S. 2018. Holding out hope for a half-way Brexit house. London: Centre for European Reform.

Stivachtis, Y., and Webber, M. 2011. Regional international society in a post-enlargement Europe. Journal of European Integration 33, no. 2: 101-116.

Vigezzi, B. 2005. The British Committee on the Theory of International Politics (1954-1985): the rediscovery of history. Milano: Edizioni Unicopli.

Wallace, W. 1999. The sharing of sovereignty: the European paradox. In R. Jackson, ed. Sovereingty at the Millennium, 81-99. Oxford: Blackwell.

Webber, D. 2014. How likely is it that the European Union will disintegrate European Journal of International Relations 20, no. 2: 341-365.

Wheeler, N. 2000. Saving strangers: humanitarian intervention in international society. Oxford: Oxford University Press.

Whitman, R. 2016. The UK and EU foreign, security and defence policy after Brexit: integrated, associated or detached? National Institute Economic Review 28.

Williams, J. 2015. Ethics, diversity and world politics: saving pluralism from itself? Oxford: Oxford University Press.

Wilson, P. 2012. The English school meets the Chicago school: towards a grounded theory of international institutions. International Studies Review 14, no. 4:567-590.

Wong, R. 2012. 'Model power or reference point? The EU and the ASEAN Charter.' Cambridge Review of International Affairs, 25 no. 4: 669-682.

Wind, M. 2017. 'Why the British conception of sovereignty was the main reason for Brexit-and why the British "Leave vote" may end up saving the EU rather than undermining the EU.' CSF-SSSUP Working Paper, no. 3.

Wright, N. 2017. Brexit and the remaking of British foreign policy. UCL Working Paper. London: UCL. 